\title{
触 New Disease Reports \\ First report of Tomato leaf curl Bangladesh virus (ToLCBV) infecting Gomphostemma niveum plants in Assam, India
}

\author{
S. Datta*, R. Budhauliya, B. Das, S. Chatterjee, A. Bora, M.G. Vairale, H.K. Gogoi and Vijay Veer \\ Molecular Virology Laboratory, Defence Research laboratory (DRDO), PO Bag No.2, Tezpur, Assam, 784001 India
}

*E-mail: sndatta1978@gmail.com

Received: 01 Dec 2014. Published: 03 May 2015. Keywords: PCR, RCA, Begomovirus, DNA-A, DNA- $\beta$

Gomphostemma niveum (Lamiaceae), is an important herbaceous, perennial plant of ethnopharmacological importance in northeastern India (Sathe \& Kaushik, 2009; Sathe et al., 2010; Dutta, 2014). To date, no report is available on pathogens infecting plants of this genus. We here report tomato leaf curl Bangladesh virus (ToLCBV) in G. niveum plants exhibiting stunted growth, vein clearing, thickening, crinkling, yellowing, and downward curling of leaves (Fig. 1). During a survey in 2010, 10 leaf samples from six $G$. niveum plants showing these symptoms and four symptomless plants were collected from laboratory experimental fields.

Total DNA was extracted from all the samples and subjected to rolling circle amplification (RCA) followed by BamHI restriction digestion. Subsequently, a PCR was done using primer pairs DengA/DengB, BF518/BR1641 and Beta01/Beta02 for amplification of DNA-A, DNA-B and DNA- $\beta$ respectively (Reddy et al., 2005). DNA extracts from symptombearing plants showed expected size PCR amplicons with DengA/DengB ( $\sim 0.5 \mathrm{~kb}$ including V2 gene of DNA-A) and Beta01/Beta02 ( 1.3 kb including $\mathrm{BC} 1$ gene of DNA-B). DNA from symptomless plants did not yield these amplicons. Attempts to amplify a DNA-B failed repeatedly, suggesting the virus to be monopartite and associated with a betasatellite. Two amplicons of DNA-A and DNA- $\beta$ were randomly selected and directly sequenced (GenBank Accession Nos. KP118992, KP118991, respectively).

A search for homologous sequences in GenBank revealed the closest homology of the G. niveum-related partial DNA-A sequences with Tomato leaf curl Bangladesh virus (ToLCBV) from tomato in India (AF188481; percentage nucleotide identity [PNI] of 98.2\%). The DNA-B sequence showed closest homology with with tomato leaf curl Bangladesh betasatellite from chilli in Bangladesh (ToLCBB, HM007099; PNI of $87.8 \%$ ). As a follow-up, we collected 10 leaf samples from eight symptomatic and two asymptomatic G. niveum plants from the same experimental fields in January 2015. Applying the identical analysis, DNA$A$ and DNA- $\beta$ sequences were detectable in all the DNA extracts from symptomatic leaves.
Taken together, our finding of ToLCBV in G. niveum plants with typical symptoms, signifying persistent natural infection, is a new record. Although the possibility of a new viral genome created by DNA recombination remains to be explored, the detected monopartite virus differed significantly from previously reported bipartite begomovirus causing leaf curl disease in tomato plants from nearby regions (Reddy et al., 2005). Interestingly, the G. niveum identified ToLCBV DNA-A was associated with the ToLCBV betasatellite. This data contrasted with the detection of tobacco curly shoot virus (TbCSV) DNA-A (KP143684) being associated with tomato leaf curl virus (ToLCV) DNA-ß (KP143683) in symptomatic tomato plants, grown in the same experimental field, during 2010 (Datta $e t$ al., unpublished). In conclusion, we report $G$. niveum as a natural host of ToLBCV and an interesting molecular epidemiology of begomovirus in this part of India.

\section{Acknowledgements}

We thank Defence R\&D Organization (DRDO), Ministry of Defence, Government of India for funding this work. We also thank Dr. R.S. Policegoudra for reviewing the manuscript.

\section{References}

Dutta B, 2014. Study of secondary metabolites of Gomphostemma niveum Hook.f. in Assam, India. Journal of Medicinal Plants Studies 2, 24-8.

Reddy RV, Colvin J, Muniyappa V, Seal S, 2005. Diversity and distribution of begomoviruses infecting tomato in India. Archives of Virology 150, 845-67. http://dx.doi.org/10.1007/s00705-004-0486-5

Sathe M, Ghorpade R, Srivastava AK, Kaushik MP, 2010. In vivo antimalarial evaluation of Gomphostenins. Journal of Ethnopharmacology 130, 171-174. http://dx.doi.org/10.1016/i.jep.2010.04.006

Sathe M, Kaushik MP, 2009. Gomphostenins: Two new antimalarial compounds from the leaves of Gomphostemma niveum. Bioorganic \& Medicinal Chemistry Letters 20, 1312-1314. http://dx.doi.org/10.1016/j.bmcl.2009.02.120

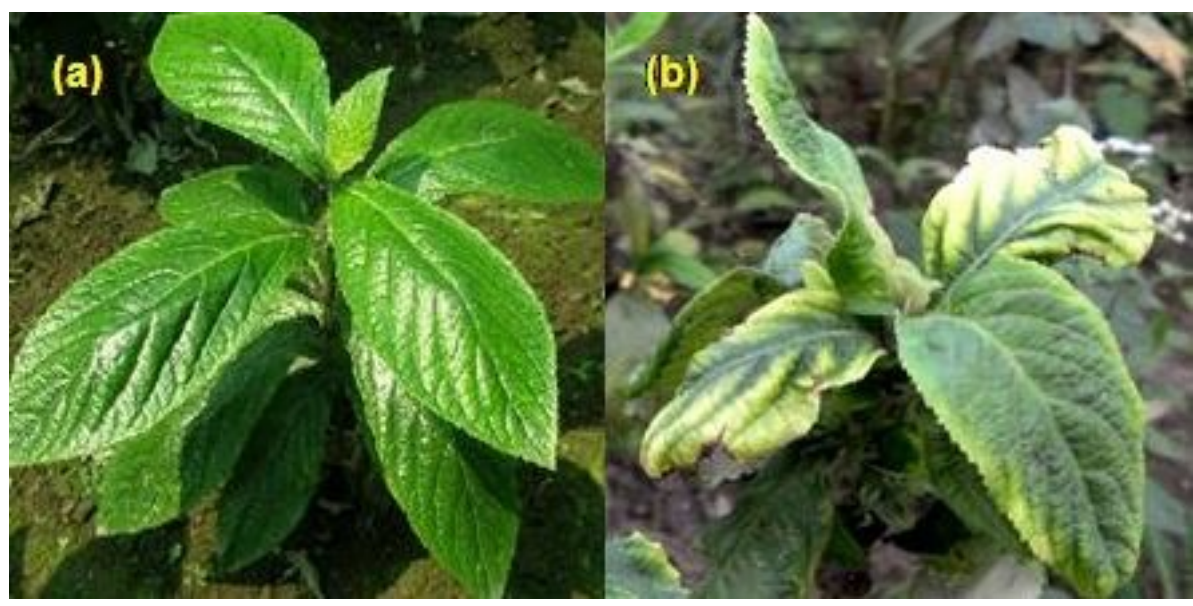

Figure 1

To cite this report: Datta S, Budhauliya R, Das B, Chatterjee S, Bora A, Vairale MG, Gogoi HK, Veer V, 2015. First report of Tomato leaf curl Bangladesh virus (ToLCBV) infecting Gomphostemma niveum plants in Assam, India. New Disease Reports $31,19$. http://dx.doi.org/10.5197/j.2044-0588.2015.031.019 (C) 2015 The Authors This report was published on-line at www.ndrs.org.uk where high quality versions of the figures can be found. 